\title{
Antibiotic Resistance Genes Among Carbapenem-resistant Enterobacterales (CRE) Isolates of Prapokklao Hospital, Chanthaburi Province, Thailand
}

\author{
Witawat Tunyong' \\ Weewan Arsheewa ${ }^{2}$ \\ Sirijan Santajit ${ }^{3,4}$ \\ Thida Kong-ngoen' \\ Pornpan Pumirat ${ }^{1}$ \\ Nitat Sookrung ${ }^{5,6}$ \\ Wanpen Chaicumpa ${ }^{6}$ \\ Nitaya Indrawattana (D) \\ 'Department of Microbiology and \\ Immunology, Faculty of Tropical Medicine, \\ Mahidol University, Bangkok, 10400 , \\ Thailand; ${ }^{2}$ Department of Microbiology, \\ Phrapokklao Hospital, Chanthaburi, \\ 22000, Thailand; ${ }^{3}$ School of Allied Health \\ Sciences, Walailak University, Nakhon Si \\ Thammarat, 80I6I, Thailand; ${ }^{4}$ Research \\ Excellence Center for Innovation and \\ Health Products, Walailak University, \\ Nakhon Si Thammarat, 8016I, Thailand; \\ ${ }^{5}$ Biomedical Research Incubation Unit, \\ Department of Research, Faculty of \\ Medicine Siriraj Hospital, Mahidol \\ University, Bangkok, 10700, Thailand; \\ ${ }^{6}$ Center of Research Excellence on \\ Therapeutic Proteins and Antibody \\ Engineering, Department of Parasitology, \\ Faculty of Medicine Siriraj Hospital, \\ Bangkok, 10700, Thailand
}

Correspondence: Nitaya Indrawattana Department of Microbiology and Immunology, Faculty of Tropical Medicine, Mahidol University, Bangkok, I0400, Thailand

Tel +66 23549100 Ext. 1598

Fax +6626435598

Email nitaya.ind@mahidol.ac.th
Background: The global spread of carbapenem-resistant Enterobacterales (CRE) inflicts a severe threat to human health. The CRE infections have resulted in an increased mortality rate in hospitals and other health-care settings worldwide. In this study, the antibioticresistance pattern and prevalence of carbapenemase-encoding genes among CRE isolated from patients of one hospital in Thailand were investigated.

Methods: By using conventional biochemical tests, we identified and isolated all species of Enterobacterales from the clinical samples kept at Prapokklao Hospital, Chanthaburi, Thailand, which were collected during 2016-2017. Multidrug-resistant (MDR) bacteria were determined by disc diffusion method and minimum inhibitory concentration (MIC) test strips. Carbapenemase genes were detected by PCR and confirmed by Sanger sequencing.

Results: Klebsiella pneumoniae complex, Escherichia coli, and Enterobacter spp. were isolated from the specimens. Of 9,564 isolated Enterobacterales, 282 were multidrug-resistance (MDR). The MIC test strips revealed that the MDR CRE were resistant to ertapenem (92.9\%) and meropenem (81.3\%). All these isolates carried carbapenemase-coding genes, including $b l a_{\mathrm{NDM}}(90 \%)$ and $b l a_{\mathrm{IMP}}(71 \%)$, the two most commonly found genes among CRE strains. There were $39.2 \%$ of the isolates that carried a combination of $b l a_{\mathrm{NDM}}-b l a_{\mathrm{IMP}}$ and $22.6 \%$ carried combined $b l a_{\mathrm{NDM}}-b l a_{\mathrm{IMP}}-b l a_{\mathrm{OXA}-48-\mathrm{like}}$ genes.

Conclusion: This study demonstrates a significantly high prevalence of CRE isolates with the MDR phenotypes. A minority of the isolates carried a single carbapenem-resistant gene, while the majority harbored multiple genes in combination. Regular monitoring of MDR CRE and characterization of their drug resistance are important for guiding treatment, intervention and control of the CRE spread and outbreak in a health-care setting.

Keywords: carbapenemase, CRE, drug resistant, Enterobacterales, nosocomial infections

\section{Introduction}

Carbapenem-resistant Enterobacterales (CRE) are gram-negative bacteria that have become pathogens of a major public health concern globally. These bacteria infect hospitalized patients who are under long-term medical care from severe entities, such as those with major surgery/injury or urinary/intravascular/respiratory catheters. ${ }^{1-3}$ Normally, CRE inhabit the digestive tract of healthy individuals or animals and are nonpathogenic. ${ }^{4}$ They become pathogens when they are misplaced into other anatomical sites, e.g., the blood stream, urinary tract, or respiratory tract, causing hospital-acquired 
diseases that encompass pneumonia, sepsis, urinary tract infection, wound infection, meningitis, etc. The infections are difficult to treat as these bacteria have propensity to resist multiple antimicrobial drugs, particularly carbapenem, which is considered the last antibiotic resort for treatment of multidrug-resistant bacterial infections. ${ }^{5,6}$ Over the past decades, increased CRE infections have been reported worldwide. ${ }^{7-16}$ The Centers for Disease Control and Prevention (CDC)'s Detect and Protect Against Antibiotic Resistance Initiative (known as the AR Initiative) and the World Health Organization (WHO) have specifically recommended the detection and tracking of CRE as a critical priority of public health. ${ }^{17,18,19}$ The most common species of CRE causing infections in the clinical settings are Klebsiella pneumoniae and Escherichia coli. ${ }^{20,21}$ The carbapenemase resistance is usually mediated by mobile genetic elements harboring betalactamase encoding genes, which also confer resistance to most penicillin-derivatives and cephalosporins. ${ }^{5}$ Meropenem, doripenem, ertapenem, and imipenem are the most commonly used carbapenems in the health-care settings. ${ }^{22}$ Carbapenemase gene products, such as $K$. pneumoniae carbapenemase (KPC), metallo- $\beta$-lactamases, and oxacillinase (OXA-48), are often found in carbapenemase-producing Enterobacterales. ${ }^{23-28}$ Among them, the bla $_{\mathrm{KPC}}$ is the most common gene reported; however, prevalence of other genes, such as $b l a_{\mathrm{OXA}}, b l a_{\mathrm{VIM}}, b l a_{\mathrm{NDM}}$, and $b l a_{\mathrm{IMP}}$ are gradually increasing worldwide. ${ }^{29}$ Emergence of drug resistant bacteria have led to more severe drug resistance problems. ${ }^{30}$ In this study, the antibiotic resistance patterns and carbapenemresistant genes among CRE isolated from the clinical samples kept in a tertiary health-care setting in Thailand were investigated as this kind of information is needed for emergency preparedness and response to outbreaks of MDR organisms in a locality.

\section{Materials and Methods Study Design, Sample Collection, and Ethical Approval}

The stored clinical samples were from a cross-sectional study conducted during January 2016 to December 2017 by the Department of Microbiology, Prapokklao Hospital, Chanthaburi Province, located about $226 \mathrm{~km}$ Southeast of Bangkok, Thailand. Of the 9,564 Enterobacterales isolates recovered from the specimens, 282 isolates $(2.95 \%)$ were CRE. They were from different types of the samples from different patients, i.e., 18 blood samples, 8 body fluids, 120 urine samples, 108 sputum samples and 28 pus samples. Unfortunately, the demographic data of the patients were untraceable. This study was approved by the Ethics Committee of Prapokklao Hospital, Chanthaburi Province, Thailand (approval number: CTIREC 041).

\section{Bacterial Isolation and Identification}

The stock samples were streaked on McConkey agar and incubated at $37^{\circ} \mathrm{C}$ for 24 hours. Isolated bacterial colonies on the plates were subjected to conventional biochemical tests $^{31}$ including oxidase, triple sugar iron utilization, ornithine decarboxylase, indole production, motility, and citrate utilization tests, as well as antimicrobial susceptibility tests. ${ }^{32}$

\section{Antimicrobial Susceptibility Testing}

The antimicrobial susceptible testing was performed based on the Clinical and Laboratory Standards Institute (CLSI) guidelines 2017. ${ }^{33}$ The Kirby-Bauer disc diffusion method and 16 antimicrobial drugs/drug combinations were used, including ampicillin $(10 \mu \mathrm{g})$, amoxicillin/clavulanate (20/10 $\mu \mathrm{g})$, ampicillin/sulbactam $(10 / 10 \mu \mathrm{g})$, piperacillin/tazobactam $(100 / 10 \mu \mathrm{g})$, cefazolin $(30 \mu \mathrm{g})$, ceftazidime $(30 \mu \mathrm{g})$, cefotaxime $(30 \mu \mathrm{g})$, ceftriaxone $(30 \mu \mathrm{g})$, ertapenem $(10$ $\mu \mathrm{g})$, meropenem $(10 \mu \mathrm{g})$, imipenem $(10 \mu \mathrm{g})$, gentamicin $(10 \mu \mathrm{g})$, amikacin $(30 \mu \mathrm{g})$, ciprofloxacin $(5 \mu \mathrm{g})$, trimethoprim/sulfamethoxazole $(1.25 / 23.75 \mu \mathrm{g})$, and fosfomycin $(200 \mu \mathrm{g})$ (Oxoid, Thermo Fisher Scientific, Basingstoke Hampshire, UK). Multidrug-resistance criteria were defined as bacteria resistant to carbapenem and at least three out of five drug groups - cephalosporins, ampicillin, $\beta$-lactam $/ \beta$ lactamase inhibitor combination, fluoroquinolones, folate pathway, and fosfomycin. Extended-spectrum $\beta$-lactamase (ESBL) production of all isolates were tested by using a combination disc test of ceftazidime with and without clavulanate, and cefotaxime with and without clavulanate (BD BBL, Identification System, New York, USA). A positive test result was defined as $\geq 5 \mathrm{~mm}$ difference in the clear zone diameter between the discs with and without clavulanate. Criteria of CLSI 2017 were used for interpretation of the antimicrobial-susceptibility results. Carbapenem resistance was determined using Liofilchem ${ }^{\circledR}$ MIC Test Strips (Liofilchem, Roseto degli Abruzzi (TE), Italy). CRE was defined as Enterobacterales organisms showing decreased susceptibility to carbapenems (MIC for imipenem $\geq 2 \mu \mathrm{g} / \mathrm{mL}$, meropenem $\geq 2 \mu \mathrm{g} / \mathrm{mL}$, or ertapenem $\geq 1 \mu \mathrm{g} / \mathrm{mL}$ ) and resistance to all third-generation cephalosporins, regardless of carbapenemase production. ${ }^{34}$ All antibiotic 
susceptibility tests were independently performed in duplicative experiments.

\section{PCR and DNA Sequencing for Detection and Identification of Carbapenemase Genes}

The genomic DNA of all CRE isolates was extracted and amplified for bla genes, including $b l a_{\mathrm{KPC}}, b l a_{\mathrm{NDM}}, b l a_{\mathrm{VIM}}$,

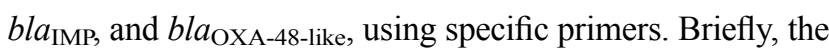
bacterial isolates were grown on tryptic soy agar plates at $37^{\circ} \mathrm{C}$ overnight. The single bacterial colony was resuspended in sterile distilled water and boiled at $100^{\circ} \mathrm{C}$ for 10 minutes. The lysates were centrifuged at $12,000 \times g$ for 10 minutes and $1 \mu \mathrm{L}$ of supernatant was used as DNA template for PCR. ${ }^{35}$ The amplification reaction $(25 \mu \mathrm{L})$ contained $10 \times$ Taq buffer, $25 \mathrm{mM}$ of $\mathrm{MgCl}_{2}, 10 \mathrm{mM}$ of dNTPs, $10 \mu \mathrm{M}$ each of of forward and reverse primers, $>50 \mathrm{ng} / \mu \mathrm{L}$ of genomic DNA and 1.25 units $/ \mu \mathrm{L}$ of Taq DNA Polymerase (Thermo Scientific, Waltham, MA, USA). The thermal cycles were $94^{\circ} \mathrm{C}$ for 5 minutes, followed by 35-cycles of denaturing at $94^{\circ} \mathrm{C}, 30$ seconds; annealing at a temperature specific for each primer, 30 seconds; and extension at $72^{\circ} \mathrm{C}, 30$ seconds, with a final extension at $72^{\circ} \mathrm{C}$ for 7 minutes. ${ }^{35} \mathrm{PCR}$ products were analyzed using $1.5 \%(\mathrm{w} / \mathrm{v})$ agarose gel and ethidium bromide staining. Individual genes in representative CRE isolates were verified by DNA sequencing. The nucleotide sequences were analyzed using the BLASTn program, software available at the National Center for Biotechnology Information website (http://www.ncbi.nlm.nih.gov).

\section{Results}

\section{Bacterial Identification and CRE Isolates}

From a total of 9,567 Enterobacterales isolates, 282 $(2.95 \%)$ were carbapenem resistant Enterobacterales (CRE). They were 187 (66\%) K. pneumoniae complex, 81 (29\%) E. coli, and 14 (5\%) Enterobacter spp., 11 (4\%) E. cloacae and 3 (1\%) E. aerogenes (Figure 1).

\section{Antimicrobial Susceptibility Testing}

Antimicrobial pattern of carbapenem-resistant Enterobacterales isolates are shown in Table 1. The 2016 CRE isolates showed high resistance to third-generation cephalosporin (100\%); carbapenem: ertapenem 99\%, meropenem $94.6 \%$, imipenem $81.9 \%$; $\beta$-lactam/ $\beta$-lactamase inhibition combination: amoxicillin/clavulanate $100 \%$, ampicillin/ sulbactam 99\%, piperacillin/tazobactam 88.3\%; and ampicillin $99 \%$. Resistance to other antibiotics was observed - ciprofloxacin $82.9 \%$, trimethoprim-sulfamethoxazole $90 \%$, amikacin $61.3 \%$, gentamicin $21.6 \%$, and fosfomycin $18 \%$. The results of the MIC test strips showed resistance to ertapenem and meropenem at 85.6 and $78.4 \%$, respectively. The MIC ranges of CRE isolates, i.e., E. coli, $K$. pneumoniae complex, and Enterobacter spp., for ertapenem were 0.5-32, $0.064-32$, and $1-32 \mu \mathrm{g} / \mathrm{mL}$, respectively, and for meropenem were $0.032-32,0.047-32$ and $2-32 \mu \mathrm{g} / \mathrm{mL}$, respectively. The CRE isolates were positive for extended-spectrum $\beta$ lactamase (ESBL); the values for ceftazidime and cefotaxime were 85.5 and $71.4 \%$, respectively (Figure 2).

The 2017 CRE isolates were highly resistant to thirdgeneration cephalosporin (cefazolin 100\%, ceftazidime

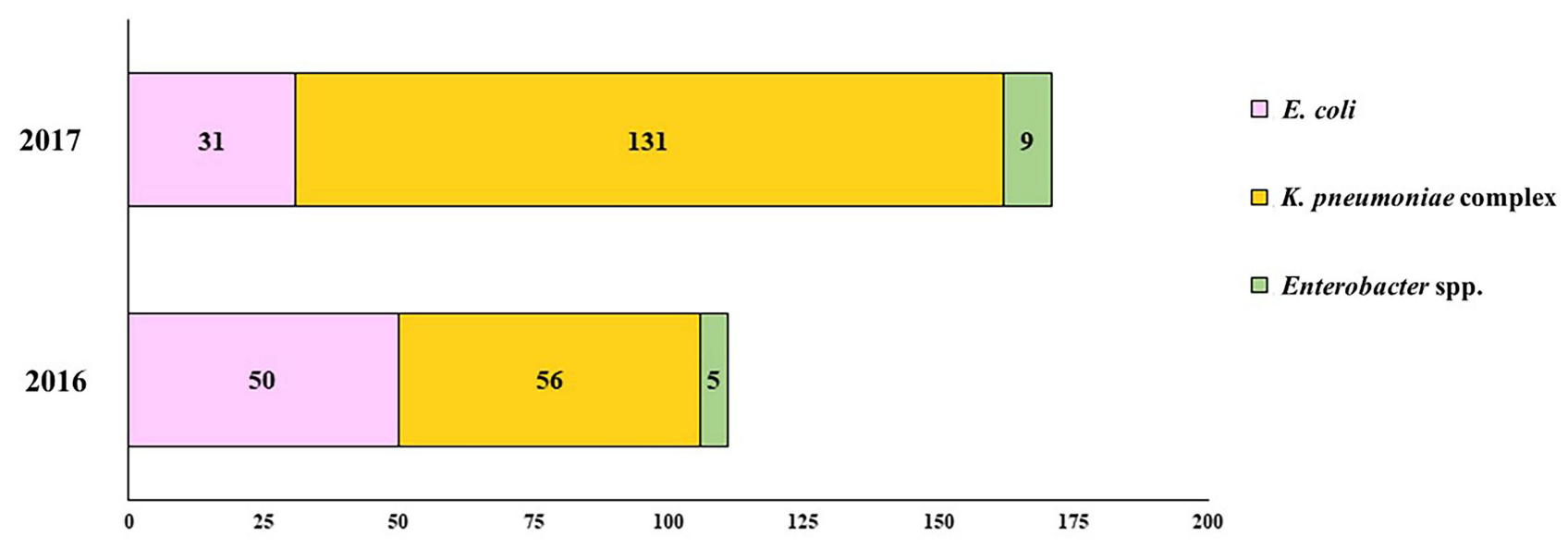

Number of bacterial isolates

Figure I Number of carbapenem-resistant Enterobacterales isolates during 2016-2017. 


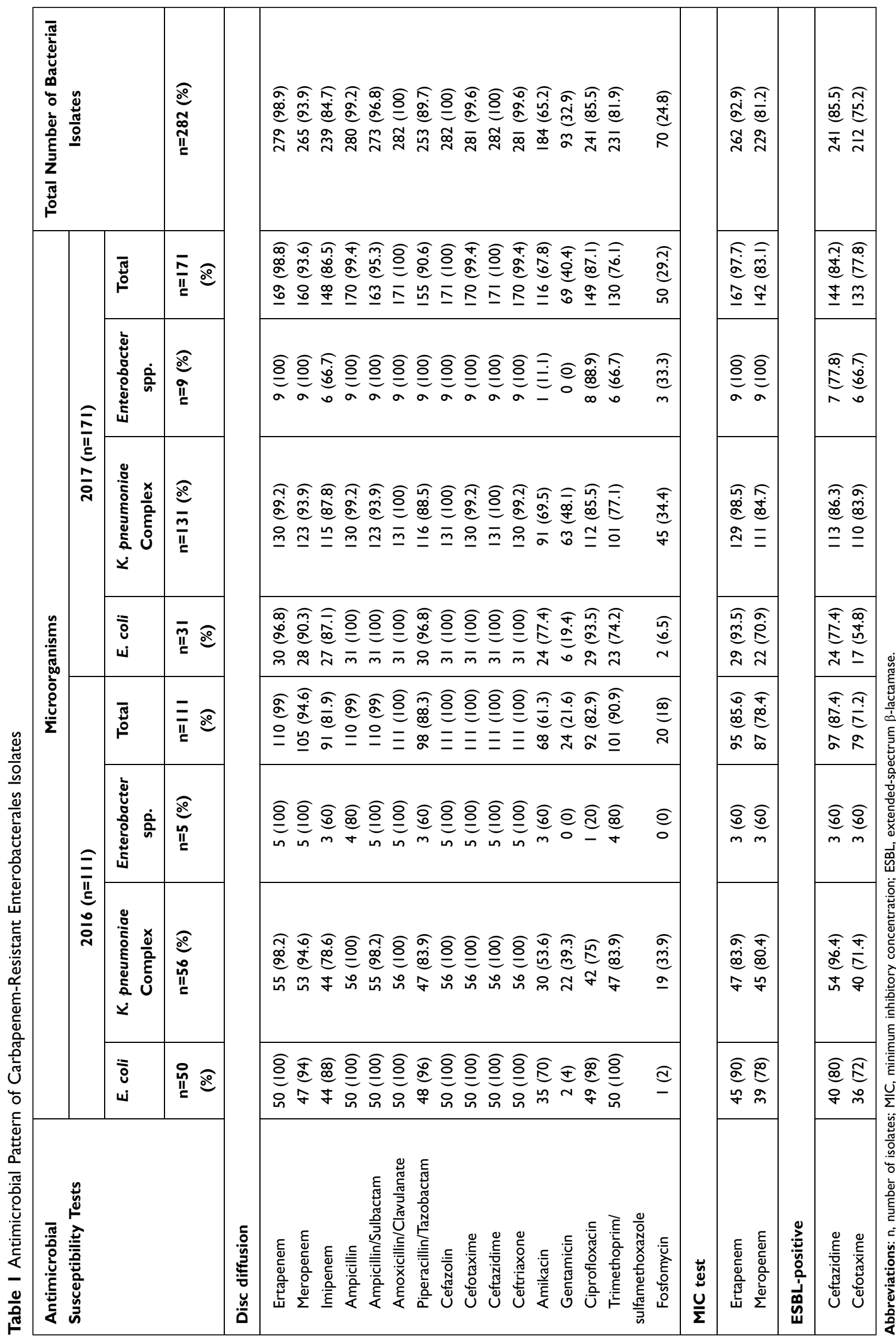


$100 \%$, cefotaxime $99.4 \%$, ceftriaxone $99.4 \%$ ); carbapenem (ertapenem 98.8\%, meropenem 93.6\%, imipenem 86.5\%); $\beta$-lactam/ $\beta$-lactamase inhibition combination (amoxicillin/ clavulanate $100 \%$, ampicillin/sulbactam $96.8 \%$, piperacillin/tazobactam 89.7\%); and ampicillin (99.2\%). Resistance to other antibiotics were-ciprofloxacin $(87.1 \%)$, trimethoprim-sulfamethoxazole $(76.1 \%)$, amikacin $(67.8 \%)$, gentamicin (40.4\%), and fosfomycin (29.2\%). The MIC test strips that demonstrated resistance to ertapenem and meropenem were 97.7 and $83.1 \%$, respectively. These CRE isolates were positive for ESBL; the values for ceftazidime and cefotaxime were 84.2 and $77.8 \%$, respectively.

\section{Carbapenemase Coding Genes Among the Carbapenem-resistant Enterobacterales}

The PCR amplicon sizes of the resistant genes, ie, bla $a_{\mathrm{KPC}}$, bla $_{\mathrm{VIM}}, b l a_{\mathrm{IMP}}, b l a_{\mathrm{NDM}}$, and bla $a_{\mathrm{OXA}-48-\text { like }}$ were 489,382 , 188, 490, 218 and 743 bp, respectively (Supplementary Data 1).

Of the $282 \mathrm{CRE}$ isolates, $256(90 \%)$ carried bla $a_{\mathrm{NDM}}$; $203(72 \%)$ and $134(48 \%)$ isolates were positive for $b l a_{\mathrm{IMP}}$ and $b l a_{\text {OXA-48-like, respectively. There were five }(1.8 \%)}$ isolates carried $b l a_{\mathrm{VIM}}$ and one $(0.4 \%)$ isolate with $b l a_{\mathrm{KPC}}$.

Distribution of the carbapenemase genes was also analyzed. Among 282 isolates, 31 were singly positive for $b l a_{\mathrm{NDM}}\left(22\right.$ isolates, $7.8 \%$ ) and $b l a_{\mathrm{IMP}}$ (9 isolates, 3.2\%). The others 251 isolates $(89 \%)$ had combination of different genes. The predominant combination was $b l a_{\mathrm{NDM}}$ and bla $a_{\mathrm{IMP}}$ (111 isolates, 39.2\%), followed by combined $b l a_{\mathrm{NDM}}, b l a_{\mathrm{IMP}}$, and bla $a_{\mathrm{OXA}-48-\mathrm{like}}$ (64 isolates, 22.6\%) and combined $b l a_{\mathrm{NDM}}$ and bla $a_{\mathrm{OXA}-48-l i k e}(55$ isolates, $19.4 \%)$. Other combination types were the $b l a_{\text {IMP }}$ and $b l a_{\mathrm{OXA}-48-l i k e}\left(15\right.$ isolates, 5.3\%), bla ${ }_{\mathrm{NDM}}$, bla $a_{\mathrm{IMP}}$ and blaOXA-48-like (3 isolates, 1.1\%), bla $a_{\mathrm{NDM}}$ and bla $\mathrm{VIM}$ combination ( 2 isolates, $0.7 \%$ ), and $b l a_{\mathrm{KPC}}, b l a_{\mathrm{IMP}}$, and $b l a_{\mathrm{OXA}-48-}$ like ( 1 isolate, $0.4 \%$ ). The orthologues of the antibioticresistant gene PCR amplicons are shown in Supplementary Data 2.

Among carbapenem-resistant bacteria, the highest prevalence of the drug-resistant gene was bla $a_{\mathrm{NDM}}$, which was found in 165 isolates $(58.5 \%)$ of K. pneumoniae complex; followed by 78 isolates $(27.7 \%)$ of E. coli. The second most prevalent

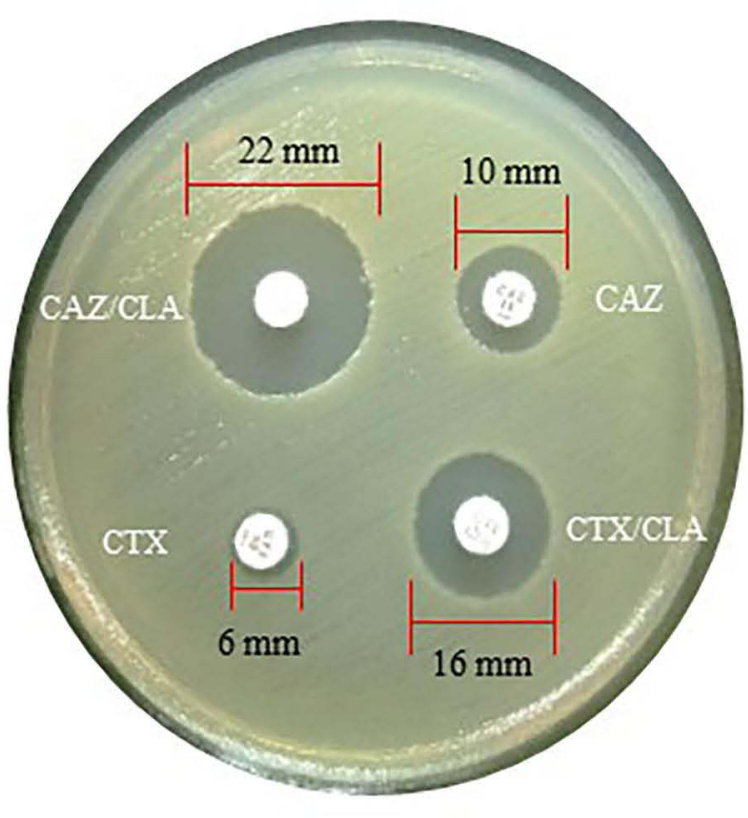

A

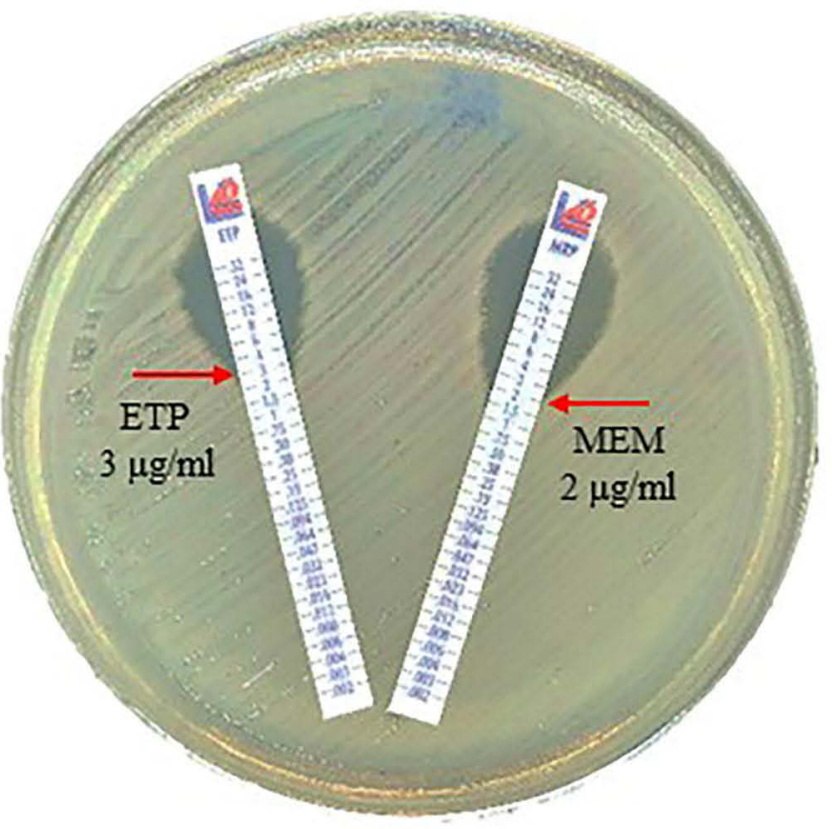

B

Figure 2 Antimicrobial susceptibility test. (A) Extended-spectrum $\beta$-lactamase (ESBL) production was determined by the combination disc test. (B) Carbapenem resistance test by MIC test strips.

Abbreviations: CAZ/CLA, ceftazidime + clavulanate; CAZ, ceftazidime + cefotaxime; CTX, cefotaxime; CTX/CLA, cefotaxime + clavulanate; ETP, ertapenem; MEM, meropenem. 
Table 2 Distribution of Carbapenemase-encoding Genes Among Carbapenemase-producing Carbapenem-resistant Enterobacterales Isolates by PCR

\begin{tabular}{|c|c|c|c|c|}
\hline \multirow[t]{2}{*}{ Carbapenemase Genes } & \multicolumn{4}{|c|}{ Microorganisms } \\
\hline & $\begin{array}{c}\text { E. coli } \\
n=8 \text { I (\%) }\end{array}$ & $\begin{array}{c}\text { K. pneumoniae complex } \\
n=187(\%)\end{array}$ & $\begin{array}{l}\text { Enterobacter spp. } \\
\qquad n=14 \text { (\%) }\end{array}$ & $\begin{array}{c}\text { Total Number of Bacterial } \\
\text { Isolates } \\
\mathbf{n}=\mathbf{2 8 2}(\%)\end{array}$ \\
\hline$b l a_{\mathrm{KPC}}$ & $0(0)$ & $0(0)$ & $0(0)$ & $0(0)$ \\
\hline$b_{l a} a_{\mathrm{VIM}}$ & $0(0)$ & $0(0)$ & $0(0)$ & $0(0)$ \\
\hline$b l a_{1 \mathrm{MP}}$ & $3(3.7)$ & $6(3.21)$ & $0(0)$ & $9(3.2)$ \\
\hline$b l a_{\text {NDM }}$ & $11(13.58)$ & $9(4.81)$ & $2(14.28)$ & $22(7.8)$ \\
\hline bla OXA-48-like & $0(0)$ & $0(0)$ & $0(0)$ & $0(0)$ \\
\hline$b l a_{\mathrm{KPC}}, b l a_{\mathrm{VIM}}$ & $0(0)$ & $0(0)$ & $0(0)$ & $0(0)$ \\
\hline$b l a_{\mathrm{KPC}}, b l a_{\mathrm{IMP}}$ & $0(0)$ & $0(0)$ & $0(0)$ & $0(0)$ \\
\hline$b l a_{\mathrm{KPC}}, b l a_{\mathrm{NDM}}$ & $0(0)$ & $0(0)$ & $0(0)$ & $0(0)$ \\
\hline$b l a_{\mathrm{KPC}}, b l a_{\mathrm{OXA}-48-\mathrm{like}}$ & $0(0)$ & $0(0)$ & $0(0)$ & $0(0)$ \\
\hline bla $_{\mathrm{VIM}}, b_{a_{I M P}}$ & $0(0)$ & $0(0)$ & $0(0)$ & $0(0)$ \\
\hline$b l a_{\mathrm{VIM}}, b l a_{\mathrm{NDM}}$ & $2(2.46)$ & $0(0)$ & $0(0)$ & $2(0.7)$ \\
\hline bla $a_{\mathrm{VIM}}, b l a_{\mathrm{OXA} \text {-48-like }}$ & $0(0)$ & $0(0)$ & $0(0)$ & $0(0)$ \\
\hline$b l a_{\mathrm{IMP}}, b l a_{\mathrm{NDM}}$ & $19(23.45)$ & $88(47.05)$ & $4(28.57)$ & III (39.4) \\
\hline bla IMP, $b l a_{\mathrm{OXA}-48-\text {-like }}$ & $0(0)$ & $14(7.48)$ & I (7.14) & $15(5.3)$ \\
\hline$b l a_{\mathrm{NDM}}, b l a_{\mathrm{OXA}-48-\mathrm{like}}$ & $22(27.16)$ & $27(14.44)$ & $6(42.85)$ & $55(19.5)$ \\
\hline$b l a_{\mathrm{KPC}}, b l a_{\mathrm{VIM}}, b l a_{\mathrm{IMP}}$ & $0(0)$ & $0(0)$ & $0(0)$ & $0(0)$ \\
\hline$b l a_{\mathrm{KPC}}, b l a_{\mathrm{VIM}}, b l a_{\mathrm{NDM}}$ & $0(0)$ & $0(0)$ & $0(0)$ & $0(0)$ \\
\hline bla $a_{\mathrm{KPC}}, b l a_{\mathrm{VIM}}, b l a_{\mathrm{OXA}-48-\text { like }}$ & $0(0)$ & $0(0)$ & $0(0)$ & $0(0)$ \\
\hline$b l a_{\mathrm{KPC}}, b l a_{\mathrm{MPP}}, b l a_{\mathrm{NDM}}$ & $0(0)$ & $0(0)$ & $0(0)$ & $0(0)$ \\
\hline$b l a_{\mathrm{KPC}}, b l a_{\mathrm{IMP}}, b l a_{\mathrm{OXA}-48-\text { like }}$ & $0(0)$ & I $(0.53)$ & $0(0)$ & I $(0.35)$ \\
\hline$b l a_{\mathrm{KPC}}, b l a_{\mathrm{NDM}}, b l a_{\mathrm{OXA}-48-\text { like }}$ & $0(0)$ & $0(0)$ & $0(0)$ & $0(0)$ \\
\hline bla $_{\mathrm{VIM}}, b l a_{\mathrm{IMP}}, b l a_{\mathrm{NDM}}$ & $2(2.46)$ & I $(0.53)$ & $0(0)$ & $3(1.1)$ \\
\hline bla $a_{\mathrm{VIM}}, b l a_{\mathrm{IMP}}, b l a_{\mathrm{OXA}-48-\text { like }}$ & $0(0)$ & $0(0)$ & $0(0)$ & $0(0)$ \\
\hline bla $a_{\mathrm{VIM}}, b l a_{\mathrm{NDM}}, b l a_{\mathrm{OXA}-48-\text { like }}$ & $0(0)$ & $0(0)$ & $0(0)$ & $0(0)$ \\
\hline bla IMP, $_{\text {, }} a_{\mathrm{NDM}}, b l a_{\mathrm{OXA}-48-\text { like }}$ & $22(27.16)$ & $41(21.93)$ & I (7.14) & $64(22.7)$ \\
\hline$b l a_{\mathrm{KPC}}, b l a_{\mathrm{VIM}}, b l a_{I \mathrm{MP}}, b l a_{\mathrm{NDM}}$ & $0(0)$ & $0(0)$ & $0(0)$ & $0(0)$ \\
\hline$b l a_{\mathrm{KPC}}, b l a_{\mathrm{VIM}}, b l a_{\mathrm{NDM}}, b l a_{\mathrm{OXA}-48-\text { like }}$ & $0(0)$ & $0(0)$ & $0(0)$ & $0(0)$ \\
\hline bla $_{\mathrm{VIM}}, b l a_{\mathrm{IMP}}, b l a_{\mathrm{NDM}}, b l a_{\mathrm{OXA}-48-\mathrm{like}}$ & $0(0)$ & $0(0)$ & $0(0)$ & $0(0)$ \\
\hline bla $a_{\mathrm{KPC}}, b l a_{\mathrm{VIM}}, b l a_{\mathrm{IMP}}, b a_{\mathrm{NDM}}, b l a_{\mathrm{OXA}-48-\mathrm{like}}$ & $0(0)$ & $0(0)$ & $0(0)$ & $0(0)$ \\
\hline
\end{tabular}

Abbreviation: $n$, number of isolates.

resistant gene was $b_{\text {IMP }}$ gene, which was found in 151 (53.5\%) of $K$. pneumoniae complex and in $46(29.1 \%)$ of $E$. coli isolates. The bla $\mathrm{OX}$ A-48-like gene was found in 82 isolates (29.1\%), and 44 isolates $(15.6 \%)$; the $b l a_{\mathrm{VIM}}$ gene was found in $4(1.4 \%)$ E. coli isolates and $1(0.4 \%) K$. pneumoniae complex isolate; and the $b l a_{\mathrm{KPC}}$ gene was found in $1(0.4 \%)$ $K$. pneumoniae complex isolate. For Enterobacter spp., the predominant resistant gene was $b l a_{\mathrm{NDM}}$ (13 isolates, $4.6 \% ; 11 \mathrm{E}$. cloacae isolates and $2 \mathrm{E}$. aerogenes isolates). Others genes were $b a_{\text {OXA-48-like }}(8$ isolates, $3 \%$; 5 E. cloacae isolates and 3 E. aerogenes isolates) and bla $_{\mathrm{IMP}}(6$ isolates, $2 \% ; 5$ E. cloacae isolates and 1 E. aerogenes isolate) (Table 2 and Figure 3).

\section{Discussion}

Carbapenem-resistant Enterobacterales (CRE) are considered nowadays as a public health threat worldwide because they are one of the major causes of death among patients with hospital-acquired infections. Regular monitoring of CRE in a particular health-care setting is rational to guide effective treatment of the infection. This study assessed the antibiotic-resistance pattern and the prevalence of the carbapenem-resistant genes among CRE isolated from clinical specimens of patients kept at Prapokklao Hospital which is one of the tertiary care hospitals in Southeastern Thailand. Our study demonstrates a high prevalence of CRE that carried a variety of carbapenem-resistance coding genes. Three species of Enterobacterales, i.e., 


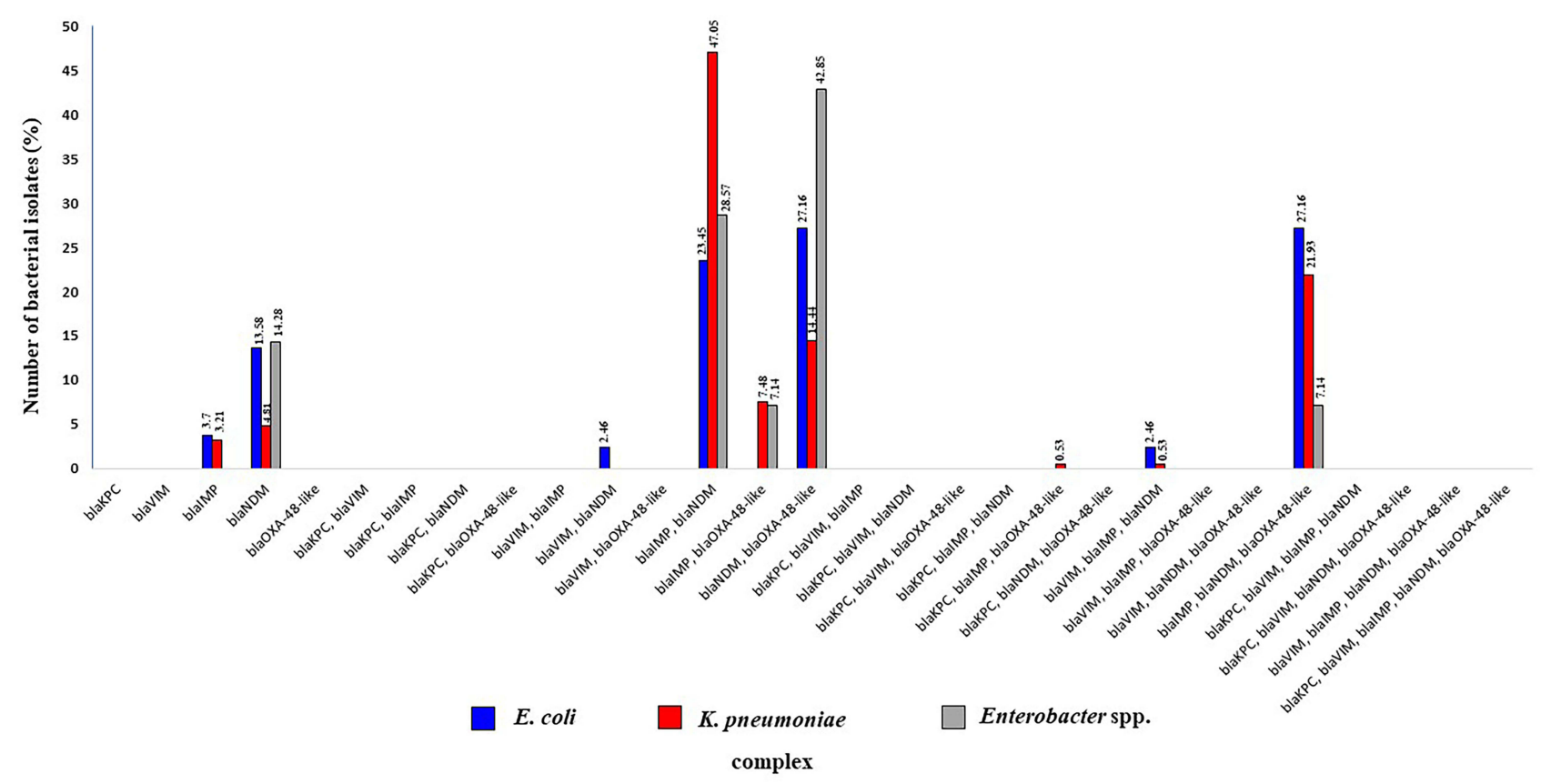

Figure 3 Percentage of carbapenemase-encoding genes among carbapenemase-producing carbapenem-resistant Enterobacterales, based on PCR analysis.

K. pneumoniae complex, E. coli, and Enterobacter spp. were predominant among the CRE isolates (282 of 9,567 Enterobacterales isolates). Five families of carbapenemase genes including bla $a_{\mathrm{KPC}}, b l a_{\mathrm{NDM}}, b l a_{\mathrm{IMP}}, b l a_{\mathrm{VIM}}$, and blaOXA-48-like were identified by PCR and DNA sequencing.

In this study, the prevalence of CRE isolated during 2016-2017 showed marked increase compared to those of 2012-2013 study in the same hospital, Prapokklao Hospital. $^{36}$ The National Antimicrobial Resistance Surveillance Center, Thailand (NARST), reported that between January and December 2017, 13\% of $K$. pneumoniae complex isolates and $1 \%$ of $E$. coli isolates were resistant to carbapenems. ${ }^{20}$ In this study, $66 \%$ of the $K$. pneumoniae complex accounted for the largest percentage of CRE isolates (50\% in 2016 and 77\% in 2017), 29\% of the E. coli and $5 \%$ of the Enterobacter spp., respectively.

Most resistance to carbapenem agents is caused by carbapenemase and the presence of other resistance mechanisms, such as extended-spectrum beta-lactamases (ESBLs), porin mutations, and/or the presence of efflux pumps. $^{37}$ While our antimicrobial susceptibility testing results showed that carbapenem-resistant Enterobacterales strains exhibited resistance to many antimicrobial agents including third generation cephalosporin, carbapenem, the $\beta$-lactam/ $\beta$-lactamase inhibition combination, ampicillin, ciprofloxacin, trimethoprim sulfamethoxazole, and amikacin, most CRE strains are still sensitive to gentamicin and fosfomycin which conformed to the results of previous studies. ${ }^{38-41}$ The results of this study showed that CRE isolates were highly resistant to carbapenem agents. The isolates were resistant to ertapenem (93\%) which was more than meropenem $(81 \%)$. The prevalence of ESBL-producing isolates (75-85\%) in this study was higher than that observed in a previous study among Thai community volunteers $(32.0-66.5 \%) .^{36}$

Among the CRE isolates of this study, the prevalence of three carbapenemase genes was high-bla $a_{\mathrm{NDM}}$, followed by $b l a_{\mathrm{IMP}}$ and $b l a_{\mathrm{OXA}-48-\text { like. The } b l a_{\mathrm{VIM}} \text { and }}$ $b l a_{\mathrm{KPC}}$ genes were found in smaller numbers in this study, even though this gene has been reported to spread rapidly worldwide. In Thailand, bla $a_{\mathrm{NDM}}, b l a_{\mathrm{OXA}-48-l i k e}$, and $b l a_{\mathrm{IMP}-14}$ were frequently detected in clinical Enterobacterales isolates, ${ }^{42}$ while the prevalence of $b l a_{\mathrm{KPC}}$ in the country remained low; the latest study reported $0.02 \%$ of $b l a_{\mathrm{KPC}-13}$-carrying isolates among Enterobacterales and $1.7 \%$ among CRE isolates. ${ }^{43}$ The prevalence of CRE in Asia and South East Asia showed an increasing trend and is mainly caused by carbapenemhydrolyzing $\beta$-lactamases, including NDM and IMP-type enzymes. $^{23,44}$ In this study, the bla $a_{\mathrm{NDM}}$ gene was found to be the most common carbapenemase gene, i.e., carried by about $90 \%$ of the tested isolates. The other most common carbapenemase genes were $b l a_{\mathrm{IMP}}$, carried by 203 isolates 
(71\%) and frequently found in $K$. pneumoniae complex (53\%); the bla $a_{\text {OXA-48-like gene, was found in } 134 \text { isolates }}$ (48\%) and 29\% among the $K$. pneumoniae complex. There are limited data on bla $a_{\mathrm{IMP}}$ and $b l a_{\mathrm{OX}}$ A-48-like in relation to CRE prevalence in Thailand. However, Rimrang et $\mathrm{al}^{43}$ reported in 2012 that two isolates of K. pneumoniae complex out of 4,818 from clinical Enterobacterales isolates were bla IMP. In addition, our results also demonstrated that $89 \%$ of the CRE contained combinations of genes. The most commonly found were the $b l a_{\mathrm{NDM}}$ and $b l a_{\mathrm{IMP}}$ gene combination (39.2\%), followed by the bla $a_{\mathrm{NDM}}$ and $b l a_{\mathrm{OXA}-48 \text {-like }}$ combination, and the $b l a_{\mathrm{IMP}}$ and $b l a_{\mathrm{OXA}-48-\text { like }}$ combination. In addition, we observed the triple combination of $b l a_{\mathrm{NDM}}, b l a_{\mathrm{IMP}}$ and $b l a_{\text {OXA-48-like }}(22.6 \%)$, and $11 \%$ of the CRE isolates with single gene, i.e., bla $a_{\mathrm{NDM}}(7.8 \%)$ and $b l a_{\mathrm{IMP}}(3.2 \%)$.

The high prevalence of CRE harboring the carbapenemase-coding genes along with multiple drug-resistan $\mathrm{t}$ phenotypes signals a decreasing therapeutic efficacy of the currently available antimicrobial agents. Thus, an effective alternative option to combat these drug resistant bacteria is urgently needed. Natural products with antibacterial activities against various gram-positive and gram-negative bacterial pathogens have been used with some success, such as essential oils (Melaleuca alternifolia, Thymus vulgaris, Mentha piperita, and Rosmarinus officinalis), a commercial ophthalmic solution containing povidone-iodine $0.6 \%\left(\right.$ IODIM $\left.^{\circledR}\right)$, hexamidine diisethionate $0.05 \%$ (Keratosept). ${ }^{45-48}$ These products should be studied further along with other novel synthetic drugs toward clinical use against the MDR CRE.

\section{Conclusion}

We have demonstrated a significantly high prevalence of carbapenem-resistant Enterobacteriales (CRE) isolates with the multidrug-resistant (MDR) phenotypes isolated from clinical samples of patients of one of the tertiary care hospitals in Thailand. The MDR CRE isolates carried carbapenemresistant genes either singly (minority) or multiple genes in combination (majority). Regular monitoring of the MDR $\mathrm{CRE}$ is needed regularly for guiding treatment, intervention and control of the spread and outbreak of these superbugs.

\section{Acknowledgments}

This work was supported by the Tropical Medicine Grants 2017 from Faculty of Tropical Medicine, Mahidol University to Witawat Tunyong. We would like to thank Mr Paul Adams, Research Administrator of Faculty of Tropical Medicine, Mahidol University, for editing English of this manuscript.

\section{Disclosure}

The authors report no conflicts of interest in this work.

\section{References}

1. Elbadawi LI, Borlaug G, Gundlach KM, et al. Carbapenem-resistant Enterobacteriaceae transmission in health care facilities-Wisconsin, February-May 2015. Morbid Mortal Wkly Rep. 2016;65 (34):906-909. doi:10.15585/mmwr.mm6534a5

2. Suay-García B, Pérez-Gracia MT. Present and future of carbapenem resistant Enterobacteriaceae (CRE) infections. Antibiotics. 2019;8 (3):122. doi:10.3390/antibiotics8030122

3. Sheu CC, Chang YT, Lin SY, Chen YH, Hsueh PR. Infections caused by carbapenem-resistant Enterobacteriaceae: an update on therapeutic options. Front Microbiol. 2019;10:80. doi:10.3389/ fmicb.2019.00080

4. Jacob JT, Klein E, Laxminarayan R, et al. Vital signs: carbapenem-resistant Enterobacteriaceae. Morbid Mortal Wkly Rep. 2013;62(9):165.

5. Tängdén T, Giske CG. Global dissemination of extensively drugresistant carbapenemase-producing Enterobacteriaceae: clinical perspectives on detection, treatment and infection control. J Intern Med. 2015;277(5):501-512. doi:10.1111/joim.12342

6. Li X, Ye H. Clinical and mortality risk factors in bloodstream infections with carbapenem-resistant Enterobacteriaceae. Can J Infect Dis Med Microbiol. 2017. doi:10.1155/2017/6212910

7. Nordmann P, Naas T, Poirel L. Global spread of carbapenemase-producing Enterobacteriaceae. Emerg Infect Dis. 2011;17(10):1791. doi:10.3201/eid1710.110655

8. Shahid M, Sobia F, Singh A, Khan HM, Malik A, Shukla I. Molecular epidemiology of carbapenem-resistant Enterobacteriaceae from a North Indian Tertiary Hospital. N Z J Med Lab Sci. 2012;66(1):5.

9. Guh AY, Bulens SN, Mu Y, et al. Epidemiology of carbapenemresistant Enterobacteriaceae in 7 US communities, 2012-2013. JAMA. 2015;314(14):1479-1487. doi:10.1001/jama.2015.12480

10. Okoche D, Asiimwe BB, Katabazi FA, Kato L, Najjuka CF. Prevalence and characterization of carbapenem-resistant Enterobacteriaceae isolated from Mulago National Referral Hospital, Uganda. PLoS One. 2015;10(8):e0135745. doi:10.1371/ journal.pone. 0135745

11. Xu Y, Gu B, Huang M, et al. Epidemiology of carbapenem resistant Enterobacteriaceae (CRE) during 2000-2012 in Asia. $J$ Thorac Dis. 2015;7(3):376.

12. Alotaibi FE, Bukhari EE, Al-Mohizea MM, Hafiz T, Essa EB, AlTokhais YI. Emergence of carbapenem-resistant Enterobacteriaceae isolated from patients in a university hospital in Saudi Arabia. Epidemiology, clinical profiles and outcomes. J Infect Public Health. 2017;10(5):667-673. doi:10.1016/j.jiph.2017.05.004

13. Almugadam BS, Ali NO, Ahmed AB. Prevalence and antibiotics susceptibility patterns of carbapenem resistant Enterobacteriaceae. J Bacteriol Mycol Open Access. 2018;6(3):187-190.

14. Chotiprasitsakul D, Srichatrapimuk S, Kirdlarp S, Pyden AD, Santanirand P. Epidemiology of carbapenem-resistant Enterobacteriaceae: a 5-year experience at a tertiary care hospital. Infect Drug Resist. 2019;12:461. doi:10.2147/IDR.S192540

15. Kang JS, Yi J, Ko MK, Lee SO, Lee JE, Kim KH. Prevalence and risk factors of carbapenem-resistant Enterobacteriaceae acquisition in an emergency intensive care unit in a tertiary hospital in Korea: a Case-Control Study. J Korean Med Sci. 2019;34(18):18. doi:10.3346/ jkms.2019.34.e140

16. Tran DM, Larsson M, Olson L, et al. High prevalence of colonisation with carbapenem-resistant Enterobacteriaceae among patients admitted to Vietnamese hospitals: risk factors and burden of disease. J Infect. 2019;79(2):115-122. doi:10.1016/j.jinf.2019.05.013 
17. Lutgring JD, Limbago BM, Kraft CS. The problem of Carbapenemase-producing-carbapenem-resistant-Enterobacteriaceae detection. J Clin Microbiol. 2016;54(3):529-534. doi:10.1128/ JCM.02771-15

18. Kost K, Yi J, Rogers B, Jerris R. Comparison of clinical methods for detecting carbapenem-resistant Enterobacteriaceae. Pract Lab Med. 2017;8:18-25. doi:10.1016/j.plabm.2017.03.002

19. Tacconelli E, Carrara E, Savoldi A, et al. Discovery, research, and development of new antibiotics: the WHO priority list of antibiotic-resistant bacteria and tuberculosis. Lancet Infect Dis. 2018;18(3):318-327. doi:10.1016/S1473-3099(17)30753-3

20. NARST. National antimicrobial resistance surveillance center, Thailand. Available from:http://narst.dmsc.moph.go.th/data/AMR\% 202000-2020-12M.pdf. Accessed July 30, 2021. Thai.

21. Partridge SR, Kwong SM, Firth N, Jensen SO. Mobile genetic elements associated with antimicrobial resistance. Clin Microbiol Rev. 2018;31(4):e00088-17. doi:10.1128/CMR.00088-17

22. Nicolau DP. Carbapenems: a potent class of antibiotics. Expert Opin Pharmacother. 2008;9(1):23-37. doi:10.1517/14656566.9.1.23

23. Logan LK, Weinstein RA. The epidemiology of carbapenem-resistant Enterobacteriaceae: the impact and evolution of a global menace. J Infect Dis. 2017;215(suppl_1):S28-S36. doi:10.1093/infdis/jiw282

24. Rhodes NJ, Wagner JL, Davis SL, et al. Trends in and predictors of carbapenem consumption across North American hospitals: results from a multicenter survey by the MAD-ID research network. Antimicrob Agents Chemother. 2019;63(7):e00327-19. doi:10.1128/ AAC.00327-19

25. Bakthavatchalam YD, Anandan S, Veeraraghavan B. Laboratory detection and clinical implication of oxacillinase-48 like carbapenemase: the hidden threat. J Glob Infect Dis. 2016;8(1):41. doi:10.4103/ 0974-777X.176149

26. Lee CR, Lee JH, Park KS, Kim YB, Jeong BC, Lee SH. Global dissemination of carbapenemase-producing Klebsiella pneumoniae: epidemiology, genetic context, treatment options, and detection methods. Front Microbiol. 2016;7:895.

27. Wang Q, Wang X, Wang J, et al. Phenotypic and genotypic characterization of carbapenem-resistant Enterobacteriaceae: data from a longitudinal large-scale CRE study in China (2012-2016). Clin Infect Dis. 2018;67(suppl 2):S196-S205. doi:10.1093/cid/ciy660

28. Park CE. Clinical laboratory aspect of carbapenem-resistant Enterobacteriaceae. Korean J Clin Lab Sci. 2020;52(1):18-27. doi:10.15324/kjcls.2020.52.1.18

29. Chen WK, Yang Y, Tan BH. Increased mortality among carbapenemase producing carbapenem-resistant Enterobacteriaceae carriers who developed clinical isolates of another genotype. Oxford Univ Press. 2019;6(2):ofz006.

30. Netikul T, Kiratisin P. Genetic characterization of carbapenem-resistant Enterobacteriaceae and the spread of carbapenem-resistant Klebsiella pneumoniae ST340 at a university hospital in Thailand. PLoS One. 2015;10(9):e0139116. doi:10.1371/ journal.pone. 0139116

31. Nordmann P, Gniadkowski M, Giske CG, Poirel L, Woodford N, Miriagou V. European network on carbapenemases. Identification and screening of carbapenemase-producing Enterobacteriaceae. Clin Microbiol Infect. 2012;18(5):432-438. doi:10.1111/j.14690691.2012.03815.x

32. Cheesbrough M. District Laboratory Practice in Tropical Countries, Part 2. Cambridge, UK: Cambridge University Press; 2005.

33. Clinical and Laboratory Standards Institute (CLSI). Performance Standards for Antimicrobial Susceptibility Testing. 27th ed. CLSI supplement M100. Wayne, PA: Clinical and Laboratory Standards Institute; 2017.
34. Lee HJ, Choi JK, Cho SY, et al. Carbapenem-resistant Enterobacteriaceae: prevalence and risk factors in a single community-based hospital in Korea. Infect Chemother. 2016;48 (3):166-173. doi:10.3947/ic.2016.48.3.166

35. Mohamed T, Yousef LM, Darweesh EI, Khalil AK, Meghezel EM. Detection and characterization of carbapenem resistant Enterobacteriacea in Sohag University Hospitals. Egypt J Med Microbiol. 2018;27(4):61-69.

36. Arsheewa W. Prevalence of carbapenemase enzyme in clinical isolates of carbapenem-resistant Enterobacteriaceae from Prapokklao Hospital in 2012-2013. J Prapokklao Hosp Clin Med Educ Cent. 2016;33(4):314-325.

37. AlTamimi M, AlSalamah A, AlKhulaifi M, AlAjlan H. Comparison of phenotypic and PCR methods for detection of carbapenemases production by Enterobacteriaceae. Saudi J Biol Sci. 2017;24 (1):155-161. doi:10.1016/j.sjbs.2016.07.004

38. Livermore DM, Warner M, Mushtaq S, Doumith M, Zhang J, Woodford N. What remains against carbapenem-resistant Enterobacteriaceae? Evaluation of chloramphenicol, ciprofloxacin, colistin, fosfomycin, minocycline, nitrofurantoin, temocillin and tigecycline. Int $J$ Antimicrob Agent. 2011;37(5):415-419. doi:10.1016/j.jiantimicag.2011.01.012

39. Yeganeh Sefidan F, Azargun R, Ghotaslou R. Fosfomycin, a therapeutic option for infections produced by multiple drug-resistant Enterobacteriaceae. Microb Res. 2016;7(1):32-36. doi:10.4081/mr.2016.6407

40. Gopichand P, Agarwal G, Natarajan M, et al. In vitro effect of fosfomycin on multi-drug resistant gram-negative bacteria causing urinary tract infections. Infect Drug Res. 2019;12:2005. doi:10.2147/ IDR.S207569

41. Mączyńska B, Paleczny J, Oleksy-Wawrzyniak M, Choroszy-Król I, Bartoszewicz M. In vitro susceptibility of multi-drug resistant Klebsiella pneumoniae strains causing nosocomial infections to fosfomycin. a comparison of determination methods. Pathogens. 2021;10(5):512. doi:10.3390/pathogens 10050512

42. Rattanaumpawan P, Choorat C, Takonkitsakul K, Tangkoskul T, Seenama C, Thamlikitkul V. A prospective surveillance study for multidrug-resistant bacteria colonization in hospitalized patients at a Thai University Hospital. Antimicrob Resist Infect Control. 2018;7 (1):1-11. doi:10.1186/s13756-018-0393-2

43. Rimrang B, Chanawong A, Lulitanond A, et al. Emergence of NDM-1-and IMP-14a-producing Enterobacteriaceae in Thailand. $J$ Antimicrob Chemother. 2012;67(11):2626-2630. doi:10.1093/jac/ dks 267

44. Kerdsin A, Deekae S, Chayangsu S, et al. Genomic characterization of an emerging $b_{\mathrm{KPC}-2}$ carrying Enterobacteriaceae clinical isolates in Thailand. Sci Rep. 2019;9(1):1-7. doi:10.1038/s41598-019-55008-x

45. Cannas S, Usai D, Pinna A, et al. Essential oils in ocular pathology: an experimental study. J Infect Dev Ctries. 2015;9(6):650-654. doi: $10.3855 /$ jidc. 6842

46. Rameshkumar G, Ramakrishnan R, Shivkumar C, et al. Prevalence and antibacterial resistance patterns of extended-spectrum beta-lactamase producing gram-negative bacteria isolated from ocular infections. Indian J Ophthalmol. 2016;64(4):303. doi:10.4103/03014738.182943

47. Pinna A, Donadu MG, Usai D, et al. In vitro antimicrobial activity of a new ophthalmic solution containing povidone-iodine $0.6 \%$ $\left(\right.$ IODIM $^{\circledR}$ ). Acta Ophthalmol. 2020;98(2):e178-e180. doi:10.1111/ aos. 14243

48. Pinna A, Donadu MG, Usai D, Dore S, Boscia F, Zanetti S. In vitro antimicrobial activity of a new ophthalmic solution containing hexamidine diisethionate $0.05 \%$ (keratosept). Cornea. 2020;39 (11):1415-1418. doi:10.1097/ICO.0000000000002375 


\section{Publish your work in this journal}

Infection and Drug Resistance is an international, peer-reviewed openaccess journal that focuses on the optimal treatment of infection (bacterial, fungal and viral) and the development and institution of preventive strategies to minimize the development and spread of resistance. The journal is specifically concerned with the epidemiology of antibiotic resistance and the mechanisms of resistance development and diffusion in both hospitals and the community. The manuscript management system is completely online and includes a very quick and fair peerreview system, which is all easy to use. Visit http://www.dovepress.com/ testimonials.php to read real quotes from published authors. 